\title{
Classe e Estratificação Social: Analise da Influencia da Teoria de "Fim das Classes" do Adeus ao Proletariado de André Gorz na Sociologia Brasileira
}

\author{
Mauricio Reis Grazia ${ }^{1}$
}

\section{Resumo}

Este trabalho tem como objetivo central evidenciar como a sociologia brasileira absorveu a tese sobre a descaracterização do proletariado como agente da revolução social exposta por André Gorz em sua obra "Adeus ao Proletariado" de 1982. Nossa hipótese é a de que a estrutura social brasileira do início dos anos 1980 era distinta daquela européia, analisada por Gorz. Nossa análise se norteia em identificar como a sociologia brasileira absorveu as teses de Gorz no processo de análise da realidade social brasileira.

Durante os anos 1970 e início dos anos 1980 a economia capitalista mundial passou por profundos processos de reestruturação produtiva, de crescimento de políticas neoliberais visando flexibilizar leis trabalhistas e diminuir a ação dos sindicatos ligados a classe trabalhadora, de diminuição do operariado fabril tipicamente fordista, de aumento da terceirização e, por fim, de crescimento do setor de serviços. Tendo em vista esse contexto histórico André Gorz defendeu que o trabalho estaria perdendo a sua centralidade para as sociedades contemporâneas e consequentemente a teoria das classes sociais de Marx também não seria mais adequada para apreender a dinâmica dos conflitos sociais que se apresentavam.

\footnotetext{
${ }^{1}$ Graduando da Universidade Federal de São Paulo, E.F.L.C.H. Telefone: (19) 97306982. E-mail: mauricio_reis_grazia@hotmail.com
} 
Diante do número cada vez maior de desempregados e de uma racionalidade econômica crescente e, para Gorz, insuperável, o trabalho deixaria de ser o eixo central de sociabilidade humana. Diante dessa problemática, Gorz, se utiliza dos pressupostos weberianos da estratificação social para repensar as possibilidades de êxodo da sociedade capitalista. Assim como Weber, Gorz vislumbra a sociedade como esferas regidas por racionalidades autônomas e confluentes, por exemplo, - as esferas econômica, religiosa, política, jurídica, e a cultural, tendo cada uma delas lógicas particulares de funcionamento que se entrecruzam. Com isso, o autor indicou a necessidade de uma regulamentação da esfera econômica por parte do estado, com a concessão de uma renda básica; diminuição do tempo de trabalho e resguarde da esfera de autonomia, para permitir aos indivíduos uma existência plena fora do trabalho possibilitando assim o êxodo do capitalismo. Nesse trabalho temos a intenção de recuperar a análise de Gorz para, primeiro, realizar uma crítica interna a sua análise, para depois, refletir sobre como autores, como, por exemplo, Ricardo Antunes, Henrique Amorim, Josué Pereira da Silva, Iram Jácome Rodrigues e Silvio Camargo que reafirmaram, ou, negam as teses expostas em o adeus o proletariado na análise da sociedade brasileira.

A partir dos resultados encontrados em nosso levantamento bibliográfico e do fichamento e análise dos artigos contemplados por essa pesquisa, acreditamos que de forma geral a incorporação da tese de "fim das classes sociais" e do "fim do trabalho" exposta na obra "Adeus ao Proletariado" de André Gorz (1980) pela sociologia brasileira se deu em três vias.

A partir dos resultados encontrados em nosso levantamento acreditamos que a incorporação e a crítica ao pensamento sociológico de 
Gorz pela sociologia brasileira se dá sobre três eixos de analise diferentes. Escolhemos apresentar aqui autores que consideramos centrais para compreender de que forma a sociologia brasileira absorveu a tese de fim das classes de Gorz. Autores como Ricardo Antunes; Silvio Camargo; Ariovaldo Santos; Ricardo Abramovay; Marcelo B. Mattos; Eleuterio F. S. Prado e Ângela Borges, apresentam a tese de que o trabalho ainda se configura como elemento central para compreensão da vida social e por tanto seria um equívoco pensar o fim do trabalho ou das classes sociais como propõem o autor francês.

A segunda vertente crítica ao pensamento de Gorz demonstra à necessidade de expandir o conceito de classe social a fim de considerar a subjetividade como fator central para se pensar o trabalho e as classes. Nessa segunda vertente, marcada por autores como Misael de Souza Santos, a incorporação de Gorz se dá por uma crítica de influência Weberiana para tentar demonstrar que é através da subjetividade, criada também no seio do trabalho, que podemos apreender de maneira mais satisfatória o processo social.

E por último, o terceiro ponto de análise sobre a teoria de "fim" do proletariado se norteia pela indicação de que a tese de Gorz, apesar de se mostrar em certo ponto pessimista diante das possibilidades revolucionárias da classe proletária, assumem a importância da tentativa de Gorz de romper com uma leitura economicista do marxismo. Na visão desses autores, a crítica de Gorz a Marx seria na verdade a crítica de uma leitura economicista do marxismo que postulava a esfera da produção como epicentro do qual floresceriam as contradições de classe. 